\title{
KINETIC PARAMETERS OF SILICON UPTAKE BY RICE CULTIVARS $^{(1)}$
}

\author{
Priscila Oliveira Martins ${ }^{(2)}$, Carlos Alexandre Costa Crusciol $^{(2)} \&$ \\ Cristiane Pilon ${ }^{(2)}$
}

\begin{abstract}
Silicon is considered an important chemical element for rice, because it can improve tolerance to biotic and abiotic stress. However, in many situations no positive effect of silicon was observed, probably due to genetic factors. The objective of this research was to monitor Si uptake kinetics and identify responses of rice cultivars in terms of $\mathrm{Si}$ uptake capacity and use. The experiment was carried out in a greenhouse of the São Paulo State University (UNESP), Brazil. The experiment was arranged in a completely randomized, factorial design with three replications. that consisted of two rice cultivars and two Si levels. Kinetic parameters $\left(V_{\text {max }}, K_{m}\right.$, and $\left.C_{\text {min }}\right)$, root morphology variables, dry matter yield, $\mathrm{Si}$ accumulation and levels in shoots and roots, uptake efficiency, utilization efficiency, and root/shoot ratio were evaluated. Higher Si concentrations in the nutrient solution did not increase rice dry matter. The development of the low-affinity silicon uptake system of the rice cultivar 'Caiapo' was better than of 'Maravilha'.
\end{abstract}

Index terms: Oryza sativa L., uptake efficiency, utilization efficiency.

\section{RESUMO: PARÂMETROS CINÉTICOS DA ABSORÇÃO DE SILÍCIO POR CULTIVARES DE ARROZ}

O silício é considerado um elemento químico importante para o arroz, pois tem proporcionado tolerância a estresses bióticos e abióticos. No entanto, em muitas situações, não tem sido constatado efeito positivo desse mineral, o que pode estar relacionado a fatores genéticos. Este trabalho teve por objetivo encontrar respostas entre cultivares de arroz quanto à capacidade de absorção e utilização do Si. O experimento foi desenvolvido em casa de vegetação, na Faculdade de Ciências Agronômicas/Unesp. O delineamento experimental

(1) This research was supported by FAPESP (São Paulo Research Foundation). Received for publication in March 24, 2011 and approved in November 11, 2011.

(2) Department of Crop Science, College of Agricultural Sciences, UNESP. José Barbosa de Barros 1780, CEP 18610-307 Botucatu (SP), Brazil. E-mails: po.martins@hotmail.com; crusciol@fca.unesp.br; cristianepilon@yahoo.com.br 


\begin{abstract}
foi inteiramente casualizado, composto por dois cultivares e dois níveis de Si, com seis repetições. Foram avaliados os parâmetros cinéticos $\left(V_{\max }, K_{m}\right.$ e $\left.C_{\min }\right)$, as características morfológicas de raizes, a massa de matéria seca, o teor e quantidade de Si acumulada, a eficiência de absorção e utilização e a relação raiz/parte aérea. A maior concentração de Si na solução nutritiva não promoveu aumento da massa de matéria seca do arroz. O cultivar Caiapó mostrou maior desenvolvimento do sistema de absorção de Si de baixa afinidade, em relação ao Maravilha.
\end{abstract}

Termos de indexação: Oryza sativa L., eficiência de absorção, eficiência de utilização.

\section{INTRODUCTION}

Beneficial effects of Si application have been observed for a number of crops, especially under biotic and abiotic stress, although its essentiality for plants has not been proved (Epstein \& Bloom, 2006). In rice it is one of the mineral elements extracted from the soil at highest quantities (Savant et al., 1997).

For rice, Si is considered a highly important mineral element because it can increase the number and size of aerenchyma - structures that conduct oxygen from the aerial part of the plant into the roots - increasing the oxidation power of $\mathrm{Fe}$ and $\mathrm{Mn}$ and decreasing their toxicity in the plant (Vermas \& Minhas, 1989; Liang et al., 2007). According to Yoshida et al. (1962), Si is present in combined silica and cellulose compounds below the cuticle. This reduces transpiration and increases the mechanical resistance of the leaves against fungal infection and insect attacks.

In many studies (Faria Junior et al.,2009; Mauad et al., 2011), no positive effect of Si was verified, even when applied to Si-poor soils and to crops under some type of stress; maybe because the $\mathrm{Si}$ leaf contents were not very different from stressfree plants fertilized with the element (Mauad et al., 2011). This discrepancy in results could be related to genetic factors, i.e., differences between cultivars with regard to their uptake capacity at low Si availability and/or to utilize the absorbed element with higher efficiency.

A mineral can be transported through the roots by two mechanisms, active and passive, which occur with and against an electrochemical potential gradient, respectively (Epstein \& Bloom, 2006). Active transportation is mediated by carriers located on the cytoplasmic cell membrane at the root-soil interface (Clarkson \& Hawkesford, 1993). According to Ma \& Takahashi (2002), Si uptake by rice is an active process, based on specific membrane proteins for this purpose, i.e., Si uptake may occur even against a concentration gradient.

Epstein \& Hagen (1952) utilized carrier studies to quantify ion uptake kinetics and demonstrated their similarity with the enzymatic kinetics of Michaelis \&
Menten (1913). Thus, the transport velocity of an ion through a membrane would be associated with the following factors: $V_{\max }$ (maximum uptake velocity when all binding sites are saturated), $\mathrm{K}_{\mathrm{m}}$ (MichaelisMenten constant, equivalent to the ion concentration at $50 \%$ of $\mathrm{V}_{\max }$ ), and $\mathrm{C}_{\min }$ (concentration at which net uptake of ions ceases before the solution is completely depleted of ions).

Epstein et al. (1963) and Elzam et al. (1964) conducted experiments with $\mathrm{K}^{+}, \mathrm{Rb}^{+}$, and $\mathrm{Cl}^{-}$, and found two uptake mechanisms working in a wide concentration range $\left(0.002-50 \mathrm{mmol} \mathrm{L}^{-1}\right)$ of these elements. At low $\mathrm{Rb}^{+}$concentrations, the uptake rate followed Michaelis-Menten kinetics, reaching a plateau at approximately $0.2 \mathrm{mmol} \mathrm{L}^{-1} \mathrm{Rb}^{+}$ (mechanism 1). At higher concentration ranges (up to $50 \mathrm{mmol} \mathrm{L}^{-1}$ ), the $\mathrm{Rb}^{+}$uptake rate significantly exceeded the maximum rate asymptotically approached by the mechanism in operation at low rates, with the appearance of a second isotherm. In fact, this second isotherm is a sum of several isotherms that appear at high concentration ranges (mechanism 2).

The range for mechanism 1 is also called HATS - High Affinity Transport System. The range for mechanism 2 represents the so-called LATS - Low Affinity Transport System. The limits between the high- (HATS) and low-affinity (LATS) systems have already been defined for $\mathrm{NH}_{4}^{+}$, with a limit concentration between the two systems of $1 \mathrm{mmol} \mathrm{L}^{-1}$ (Wang et al., 1993; Kronzucker et al., 1996).

According to Epstein \& Bloom (2006), the same type of mechanism applies to the transport of neutral solutes, such as sugars and silicic acid. However, $\mathrm{Si}$ uptake experiments at concentrations higher than $2.0 \mathrm{mmol} \mathrm{L}^{-1} \mathrm{Si}$ are unfeasible, because contrary to most minerals, $\mathrm{Si}$ (silicic acid) starts to polymerize at concentrations $>2.0 \mathrm{mmol} \mathrm{L}^{-1}$ at $25^{\circ} \mathrm{C}$.

In addition to the $\mathrm{Si}$ concentration, bioavailability dynamics also play a role, i.e., by means of a plant's own genetic traits, it naturally interferes with nutrient availability in the soil. Therefore, the uptake mechanisms at the soil-root interface are influenced by physiological efficiency and by the plant root morphology, i.e., root length, surface, and mean diameter (Barber, 1984). 
Consequently, the hypothesis to explain the discrepancy in rice response to Si supply is associated with differences in the Si uptake capacity of cultivars at high and low availability.

The objective of this study was to identify any differences between two rice cultivars with regard to their Si uptake and utilization efficiency by means of uptake kinetic parameters in environments with high and low availability of this mineral.

\section{MATERIAL AND METHODS}

The experiment was carried out in a greenhouse of the College of Agricultural Science, UNESP, Botucatu, São Paulo State, Brazil, in a completely randomized design, consisting of two rice cultivars with different Si accumulation (1- high accumulation: Caiapó; and 2- low accumulation: Maravilha) and two Si doses in solution (high: $1.7 \mathrm{mmol} \mathrm{L}^{-1}$; and low: $0.1 \mathrm{mmol} \mathrm{L}^{-1}$ ), with six replicates.

The rice seeds were placed to germinate on filter paper. The paper was rolled up, moistened, and placed in a germinator at a mean temperature of $25^{\circ} \mathrm{C}$ and $8 \mathrm{~h}$ light. At radicle emergence, the paper rolls were placed vertically in plastic containers with a nutrient solution layer of approximately $10 \mathrm{~cm}$ (Furlani \& Furlani, 1988, modified), at 1/4 ionic strength. The containers were maintained in a greenhouse at room temperature $\left(22-27^{\circ} \mathrm{C}\right)$.

Emergence occurred after 8 days; 2 days later, the plantlets were previously selected for health and uniformity and transferred to $4.2 \mathrm{~L}$ plastic pots $(11.0 \times 13.5 \times 28.0 \mathrm{~cm})$, fixed on styrofoam plates. Each pot received 6 rice plantlets; the pots were equipped so that the $4.0 \mathrm{~L}$ nutrient solution was sparged with an oil-free air compressor for $12 \mathrm{~h}$ a day, with low air injection, from 6:30 am to $6: 30 \mathrm{pm}$. A modified nutrient solution of Furlani \& Furlani (1988) was used, containing ( $\left.\mathrm{mg} \mathrm{L}^{-1}\right)$ : $\mathrm{Ca}=151, \mathrm{~K}$ $=141, \mathrm{Mg}=17, \mathrm{P}=6, \mathrm{~N}-\mathrm{NO}_{3}=138, \mathrm{~N}-\mathrm{NH}_{4}=20$, $\mathrm{S}=56, \mathrm{Cl}=33, \mathrm{Fe}=3.6, \mathrm{Mn}=0.5, \mathrm{~B}=0.27, \mathrm{Zn}=$ $0.15, \mathrm{Cu}=0.04, \mathrm{Mo}=0.08$, as $\mathrm{Ca}\left(\mathrm{NO}_{3}\right)_{2} \cdot 4 \mathrm{H}_{2} \mathrm{O}, \mathrm{KCl}$, $\mathrm{MgSO}_{4} .7 \mathrm{H}_{2} \mathrm{O}, \mathrm{KH}_{2} \mathrm{PO}_{4}, \mathrm{NH}_{4} \mathrm{NO}_{3}, \mathrm{~K}_{2} \mathrm{SO}_{4}, \mathrm{KNO}_{3}$, Fe-EDTA prepared with NaEDTA and $\mathrm{FeSO}_{4} \cdot 7 \mathrm{H}_{2} \mathrm{O}$, $\mathrm{MnCl}_{2} .4 \mathrm{H}_{2} \mathrm{O}, \mathrm{H}_{3} \mathrm{BO}_{3}, \mathrm{ZnSO}_{4} .7 \mathrm{H}_{2} \mathrm{O}, \mathrm{CuSO}_{4} .5 \mathrm{H}_{2} \mathrm{O}$, and $\mathrm{Na}_{2} \mathrm{MoO}_{4} \cdot 2 \mathrm{H}_{2} \mathrm{O}$. Silicic acid was used as $\mathrm{Si}$ source, prepared by passing potassium silicate (brand name FertiSil), diluted to $10 \%$ in deionized water, through cation exchange resin.

Initially, the ion strength of the nutrient solution was $1 / 10$. After 7 days the solution was replaced with a solution of $1 / 2$ ion strength; in the third week, a complete nutrient solution containing $\mathrm{Si}$ doses was applied. The solution $\mathrm{pH}$ was measured daily and maintained at around 5.5 (corrections with $0.1 \mathrm{~mol} \mathrm{~L}^{-1} \mathrm{HCl}$ or $\mathrm{NaOH}$ solutions).
The plantlets were assessed 25 and 40 days after transplanting. The kinetic uptake parameters were determined when Si concentration in the nutrient solution started to decrease, according to the method described by Claassen \& Barber (1974). To that effect, the solutions were replaced, and $\mathrm{Si}$ was omitted for $24 \mathrm{~h}$. Next, another nutrient solution containing 1.7 or $0.1 \mathrm{mmol} \mathrm{L}^{-1} \mathrm{Si}$ was added to a $1.5 \mathrm{~L}$ volume after 25 days and to $3.0 \mathrm{~L}$ after 40 days, so as to maintain the entire root system submerged in solution to allow complete Si uptake time in less time, since the volume doubled in the last evaluation (40 days).

After $30 \mathrm{~min}$ - sufficient time to allow the rice plants to reach a steady state (Epstein \& Hagen, 1952) - $10 \mathrm{~mL}$ samples were collected from the nutrient solution every $15 \mathrm{~min}$ in the first two hours; every $30 \mathrm{~min}$ in the following $4 \mathrm{~h}$; every $60 \mathrm{~min}$ in the subsequent $6 \mathrm{~h}$; at the end of $24 \mathrm{~h}$; and then every 12 hours until the Si concentration remained constant. The volume in the pots was maintained constant, and the removed solution was replaced with deionized water, according to the methodology proposed by Claassen \& Barber (1974). The Si content in the samples was determined by the method described by Elliott \& Snyder (1991), adapted by Korndörfer et al. (1999). The kinetic parameters were calculated using the Cinética software (Ruiz \& Fernandes Filho, 1992), and Si uptake velocity curves were fitted using the Sigma Plot 10.0 program. $\mathrm{C}_{\min }$ (concentration in $\mu \mathrm{mol} \mathrm{L}{ }^{-1}$, at which Si net flow is null) was estimated by the average Si concentrations in the exhaust solution, from the point at which they tended to remain constant, i.e., when no statistical difference was observed between the points.

At the end of the solution sampling period, the plants were harvested and separated in aerial part (shoots) and roots. One root sample was taken from each experimental unit; samples were extracted along the entire root length, from the root collar down to the tip of the root system. Samples were stored in $100 \mathrm{~mL}$ plastic pots with $70 \%$ alcohol solution in an air-conditioned room for subsequent morphological analysis.

The variables root length, surface, and mean diameter were evaluated using a specifically developed scanner together with software WinRhizo, based on the method of Tennant as operating principle (1975).

The aerial part of the plants and their root systems, together with the samples used for the morphological determinations were washed in running water and dried to constant weight in a forced air circulation oven at $65{ }^{\circ} \mathrm{C}$. The material was then weighed and ground in a Willey-type mill, and Si contents in the plant tissues determined, according to the technique described by Elliott \& Snyder (1991), adapted by Korndörfer et al. (1999). Si accumulation was determined as the product of the content multiplied by dry matter values. 
Uptake efficiency was estimated by the ratio: $(\mathrm{UE})=($ total $\mathrm{Si}$ accumulation in the plant expressed in $\mathrm{mg}$ )/(root dry matter yield in g), according to Swiader et al. (1994); Si utilization efficiency was calculated as follows: $($ UTLE $)=($ total dry matter yield in $\mathrm{g})^{2} /$ (total $\mathrm{Si}$ accumulation in the plant expressed in $\mathrm{mg}$ ), according to Siddiqi \& Glass (1981). The root/aerial part ratio was determined by dividing root dry matter by aerial dry matter yield.

The data were subjected to analysis of variance and the means compared by the LSD test at $5 \%$ significance, using SISVAR software (Ferreira 2000).

\section{RESULTS AND DISCUSSION}

Based on the analysis of variance (Table 1) a significant effect was verified for the factors and the interaction for all variables. However, based on the mean comparison analysis (Table 2), it was observed that $\mathrm{Si}$ rates did not influence dry matter yield of the aerial part (DMAEP), roots (DMRT), and total dry matter yield (TDMY). Korndörfer et al. (2010), Faria Junior et al. (2009), and Mauad et al. (2003) found no significant effects of Si fertilization either on dry matter yield in pasture and rice. This is due to the fact that $\mathrm{Si}$ is related to a structural function, not to growth processes such as cell elongation and multiplication. Rice is a Si-accumulating plant; $\mathrm{Si}$ is accumulated in the cell walls of the leaf cuticle in the form of amorphous silica $\left(\mathrm{SiO}_{2} \cdot \mathrm{nH}_{2} \mathrm{O}\right)$, thus contributing to improve the plant architecture (Ma et al., 2001).

In addition, Si can interfer with productivity and influences yield stability, i.e., when the plant is exposed to some sort of stress, increased Si doses may reduce impacts on yield, resulting in significant differences in relation to plants that did not receive Si.

Of the cultivars, the DMAEP of Caiapó was higher than of Maravilha, after 25 as well as 40 days. An inversion of this tendency only occurred for DMRT after 40 days, at the dose of $1.7 \mathrm{mmol} \mathrm{L}^{-1} \mathrm{Si}$ (Table 2). After 25 days, the TDMY variable reflected the results obtained for DMAEP and DMRT, i.e., a higher TDMY was observed for Caiapó (Table 2).

Table 1. F values and their respective significance, from the analysis of variance for dry matter yield of the aerial part (DMAEP), root (DMRT), and total dry matter yield (TDMY), root length (LGTH), surface (SFC), and diameter (RTD), Si uptake kinetic parameters $V_{\max }, K_{m}$, and $C_{\min }$, Si content in the aerial part (SiAEP) and root (SiRT), Si accumulation in the aerial part (SAAEP), root (SART), and the entire plant (SAEP), Si uptake efficiency (UE), Si utilization efficiency (UTLE), and root/aerial ratio (RT/AEP) of rice cultivars at different Si concentrations in the nutrient solution 25 and 40 days after transfer into growth solution

\begin{tabular}{|c|c|c|c|c|c|c|c|c|}
\hline \multirow{2}{*}{ Factor } & \multicolumn{8}{|c|}{ Day } \\
\hline & 25 & 40 & 25 & 40 & 25 & 40 & 25 & 40 \\
\hline \multirow{5}{*}{$\begin{array}{l}\text { Cultivar (C) } \\
\mathrm{Si} \\
\mathrm{C} \times \mathrm{Si}\end{array}$} & \multicolumn{2}{|c|}{ AGDM } & \multicolumn{2}{|c|}{ RTDM } & \multicolumn{2}{|c|}{ TDMY } & \multicolumn{2}{|c|}{ LGTH } \\
\hline & $13.6^{* *}$ & $14.3^{* *}$ & $4.5^{*}$ & $6.8^{*}$ & $14.1^{*}$ & $7.0 *$ & $0.8 \mathrm{~ns}$ & $1.7 \mathrm{~ns}$ \\
\hline & $0.02 \mathrm{~ns}$ & $0.04 \mathrm{~ns}$ & $0.2 \mathrm{~ns}$ & $3.3 \mathrm{~ns}$ & $0.0 \mathrm{~ns}$ & $0.05 \mathrm{~ns}$ & $0.8 \mathrm{~ns}$ & $3.8 \mathrm{~ns}$ \\
\hline & $3.9 *$ & $3.5^{*}$ & $3.0 *$ & $3.7 *$ & $3.5 *$ & $3.6^{*}$ & $3.0 *$ & $4.1 *$ \\
\hline & \multicolumn{2}{|c|}{$\mathrm{SFC}$} & \multicolumn{2}{|c|}{ RTD } & \multicolumn{2}{|c|}{$\mathrm{V}_{\max }$} & \multicolumn{2}{|c|}{$\mathrm{K}_{\mathrm{m}}$} \\
\hline Cultivar (C) & $0.1 \mathrm{~ns}$ & $4.9 *$ & $2.7 \mathrm{~ns}$ & $6.3 *$ & $0.5 \mathrm{~ns}$ & $29.4^{* *}$ & $0.9 \mathrm{~ns}$ & $8.7 * *$ \\
\hline $\mathrm{Si}$ & $0.2 \mathrm{~ns}$ & $4.3 *$ & $2.1 \mathrm{~ns}$ & $0 \mathrm{~ns}$ & $46.7 * *$ & $106.2^{* *}$ & $275.6^{* *}$ & $175.3^{* *}$ \\
\hline \multirow[t]{2}{*}{$\mathrm{C} \times \mathrm{Si}$} & $3.0 *$ & $4.0 *$ & $3.2^{*}$ & $7.4^{*}$ & $4.1^{*}$ & $35.5 * *$ & $4.3 *$ & $5.6^{*}$ \\
\hline & \multicolumn{2}{|c|}{$\mathrm{C}_{\min }$} & \multicolumn{2}{|c|}{ SiAEP } & \multicolumn{2}{|c|}{ SiRT } & \multicolumn{2}{|c|}{ SAAEP } \\
\hline Cultivar (C) & $7.6^{*}$ & $4.6 *$ & $3.6 \mathrm{~ns}$ & $23.0 * *$ & $6.7^{*}$ & $0.1 \mathrm{~ns}$ & $2.8 \mathrm{~ns}$ & $0.5 \mathrm{~ns}$ \\
\hline $\mathrm{Si}$ & $11.1 * *$ & $11.3 * *$ & $356.7 * *$ & $3113.0 * *$ & $22.0 * *$ & $20.9 * *$ & $773.9 * *$ & $326.7 * *$ \\
\hline \multirow[t]{2}{*}{$\mathrm{C} \times \mathrm{Si}$} & $8.6 * *$ & $3.8^{*}$ & $4.0 *$ & $4.5 *$ & $4.2^{*}$ & $3.0 *$ & $3.3^{*}$ & $3.7 *$ \\
\hline & \multicolumn{2}{|c|}{ SART } & \multicolumn{2}{|c|}{ SAEP } & \multicolumn{2}{|c|}{ UE } & \multicolumn{2}{|c|}{ UTLE } \\
\hline Cultivar (C) & $0.7 \mathrm{~ns}$ & $24.8 * *$ & $3.1 \mathrm{~ns}$ & $0.3 \mathrm{~ns}$ & $9.6 * *$ & $11.5^{* *}$ & $3.1 \mathrm{~ns}$ & $100.3 * *$ \\
\hline $\mathrm{Si}$ & $3.7 \mathrm{~ns}$ & $5.9 *$ & $822.9 * *$ & $318.8 * *$ & $314.8 * *$ & $216.0 * *$ & $129.3^{* *}$ & $317.6^{* *}$ \\
\hline $\mathrm{C} \times \mathrm{Si}$ & $3.0 *$ & $4.1 *$ & $3.3^{*}$ & $3.5^{*}$ & $11.6 * *$ & $50.3 * *$ & $5.0 *$ & $94.5 * *$ \\
\hline \multicolumn{3}{|c|}{ RT/AEP } & & & & & & \\
\hline Cultivar (C) & $0.1 \mathrm{~ns}$ & $48.9 * *$ & & & & & & \\
\hline $\mathrm{Si}$ & $0.2 \mathrm{~ns}$ & $7.5 *$ & & & & & & \\
\hline $\mathrm{C} \times \mathrm{Si}$ & $3.0 *$ & $3.9 *$ & & & & & & \\
\hline
\end{tabular}

**, *, and ns: significant at 1, $5 \%$, and non significant. 
Table 2. Dry matter weight of the aerial part (DMAEP), root (DMRT), and total dry matter yield (TDMY), root length, surface, and diameter of rice cultivars at different silicon concentrations in the nutrient solution 25 and 40 days after transfer into the growth solution

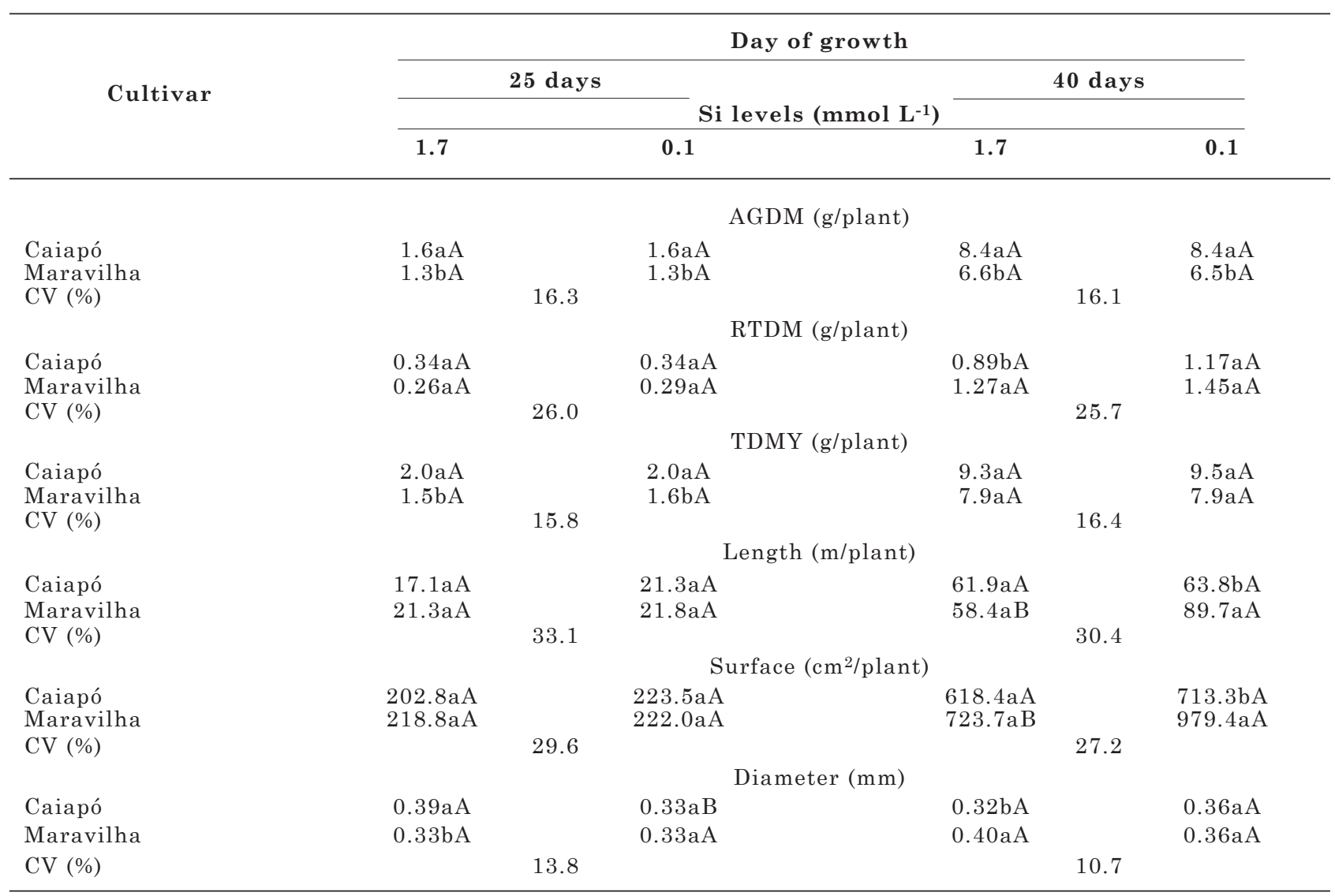

Means followed by the same lower case letter in the column, and by the same upper case letter in the row, did not differ from one another by the LSD test at $5 \%$. CV: coefficient of variation.

After 40 days, the root length and surface of Maravilha were smaller (Table 2) at the dose of $1.7 \mathrm{mmol} \mathrm{L}^{-1}$ than at $0.1 \mathrm{mmol} \mathrm{L}^{-1} \mathrm{Si}$, equivalent to a $35 \%$ decrease in root length and $26 \%$ in root surface. Between cultivars, greater length (29\%) and root surface $(27 \%)$ were observed for Maravilha than Caiapó at the dose of $0.1 \mathrm{mmol} \mathrm{L}^{-1} \mathrm{Si}$.

After 25 days, the root diameter in cultivar Caiapó increased significantly with the application of the higher Si dose. In the comparison of cultivars, at the higher Si dose, the root diameter of Caiapó was greater than of Maravilha; after 40 days, however, an inversion occurred in the behavior of this variable, and Maravilha had a greater diameter (Table 2). Similar results - increased root diameter as nutrient doses increased - were also observed by Corrêa et al. (2006) and Pavinato et al. (2009), by the application of boron to rice crops.

Smaller root diameters may increase the uptake and translocation velocity of a mineral, because the thinner the root, the shorter the way from the plasmalemma to the xylem and phloem vessels.
This behavior can be observed in table 3, where the uptake velocity value of Caiapó was higher than of Maravilha after 40 days. The differential behavior between rice cultivars for root diameter may also be attributed to the specific genetic traits of each cultivar.

The Si depletion curves in the nutrient solution show the differences in Si uptake between cultivars at both $\mathrm{Si}$ doses and both evaluation times (Figure 1). Therefore, it can be inferred that Maravilha absorbed Si from the solution more slowly than Caiapó, once again demonstrating differences between cultivars in the mineral uptake process.

The values of Si uptake kinetic parameters varied with Si concentration in the solution (Table 3). $\mathrm{K}_{\mathrm{m}}$ values, which represent the affinity of the transport system with the ion to be transported, were lower at the $0.1 \mathrm{mmol} \mathrm{L}^{-1} \mathrm{Si}$ dose, allowing the inference that at this dose a high-affinity transport system was predominant, while at $1.7 \mathrm{mmol} \mathrm{L}^{-1} \mathrm{Si}$ a low-affinity system was predominant, graphically represented by two isotherms (Figure 2). Similar results 


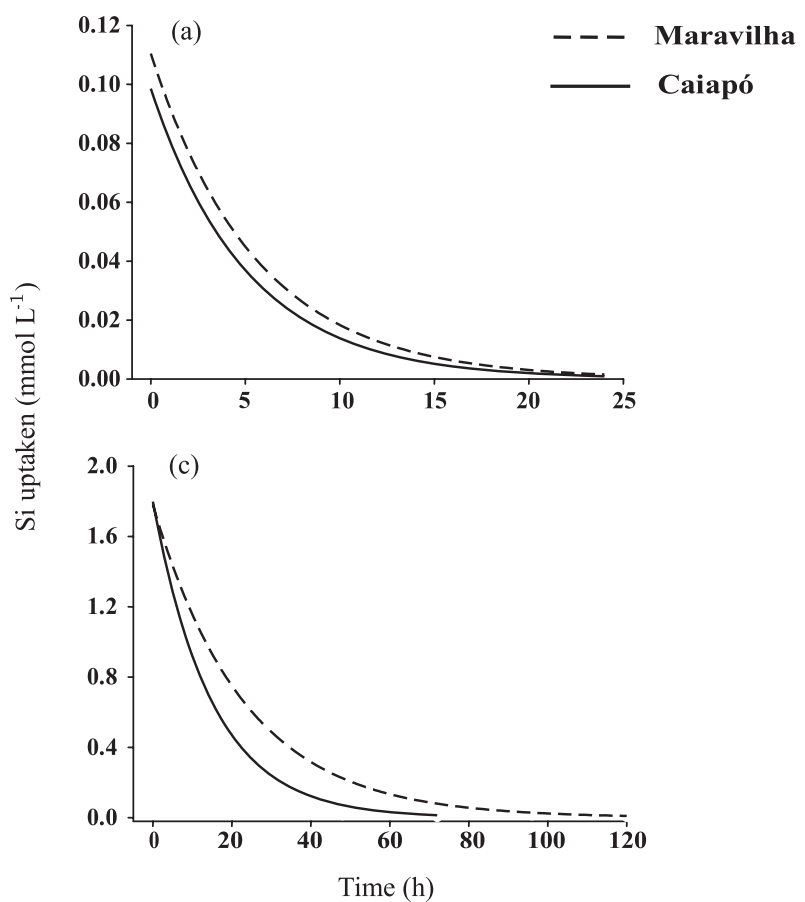

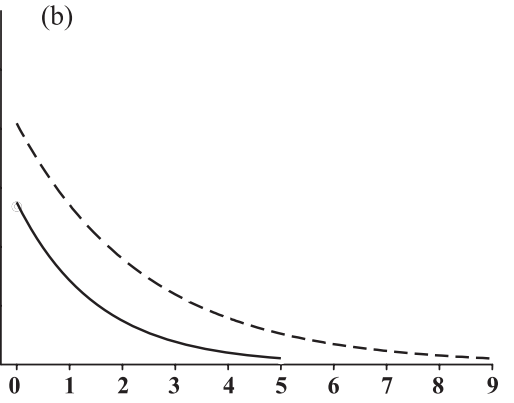

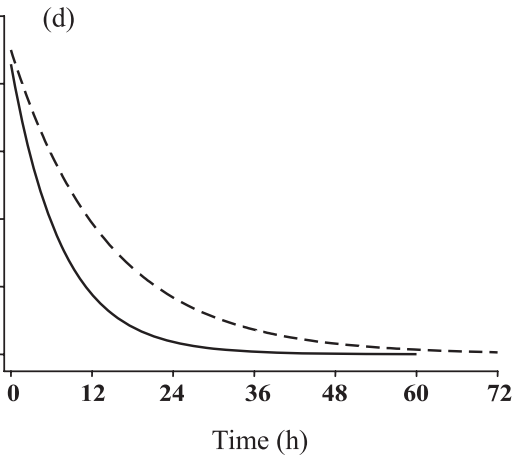

Figure 1. Depletion curve of Si contained in the growth solution with $0.1 \mathrm{mmol} \mathrm{L}^{-1}$ (a) and (b) and $1.7 \mathrm{mmol} \mathrm{L}^{-1}$ (c) and (d) Si applied 25 days (a) and (c) and 40 days (b) and (d) after transplanting rice cultivars.

Table 3. Kinetic parameters $V_{\max }$ (maximum velocity), $K_{m}$, and $C_{\min }$ for Si uptake and Si content in the aerial part (AEP) and root (RT) by rice cultivars at different silicon concentrations in the nutrient solution 25 and 40 days after transfer into the growth solution

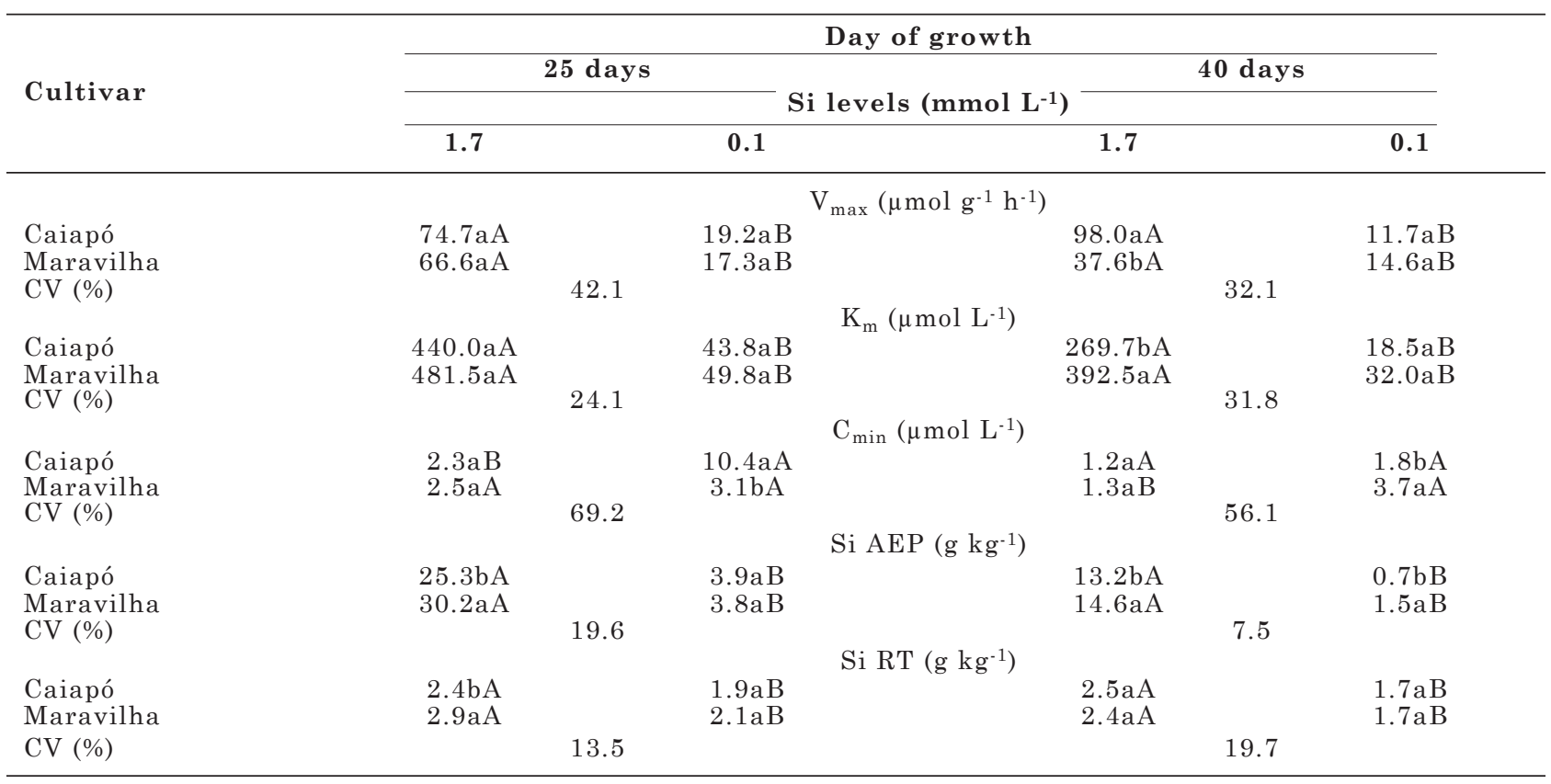

Means followed by the same lower case letter in the column, and by the same upper case letter in the row, did not differ from one another by the LSD test at $5 \%$. CV: coefficient of variation.

were found by Borges et al. (2009) in a study that evaluated ammonium uptake kinetics at low and high doses (1.43 and $8.57 \mathrm{mmol} \mathrm{L}^{-1} \mathrm{~N}$, respectively) in corn varieties. 
According to Malavolta (2006), when the range of external concentrations is sufficiently broad, two and sometimes more isotherms may occur, instead of a single one. The so-called double pattern is interpreted as a result of the operation of two carriers: in the smaller concentration range, a carrier would operate for the element with which it has higher affinity, while in the higher concentration range, a carrier would operate for the ion with which it has lower affinity.

According to Wang et al. (1993), the $\mathrm{K}_{\mathrm{m}}$ values of high- and low-affinity transport systems differ. Since $\mathrm{K}_{\mathrm{m}}$ represents the substrate concentration at which the transport process reaches half of the maximum velocity, the affinity for the substrate is the most relevant parameter in describing ion transport systems involving plant nutrient uptake (Wirén et al., 2000).

After 25 days, no significant differences were observed for $\mathrm{V}_{\max }$ (maximum uptake velocity), which reflects the uptake capacity of a given ion, or $\mathrm{K}_{\mathrm{m}}$ between cultivars (Table 3). However, after 40 days at the dose of $1.7 \mathrm{mmol} \mathrm{L}^{-1} \mathrm{Si}$, the $\mathrm{V}_{\max }$ $\left(98.0 \mu \mathrm{mol} \mathrm{g}^{-1} \mathrm{~h}^{-1}\right)$ of cultivar Caiapó was higher and $\mathrm{K}_{\mathrm{m}}\left(269.7 \mu \mathrm{mol} \mathrm{L}^{-1}\right)$ lower than of Maravilha. These $\mathrm{V}_{\max }$ values differ from those reported by Tamai \& Ma (2003), $\left(V_{\max }=221 \mu \mathrm{mol} \mathrm{g}^{-1} \mathrm{~h}^{-1}\right)$, whereas the $\mathrm{K}_{\mathrm{m}}$ values were similar $\left(\mathrm{K}_{\mathrm{m}}=320 \mu \mathrm{mol} \mathrm{L}^{-1}\right)$. Possibly, this difference in $V_{\max }$ values was due to a difference in uptake efficiency between cultivars, or due to different growing conditions in the experiments, although similar.

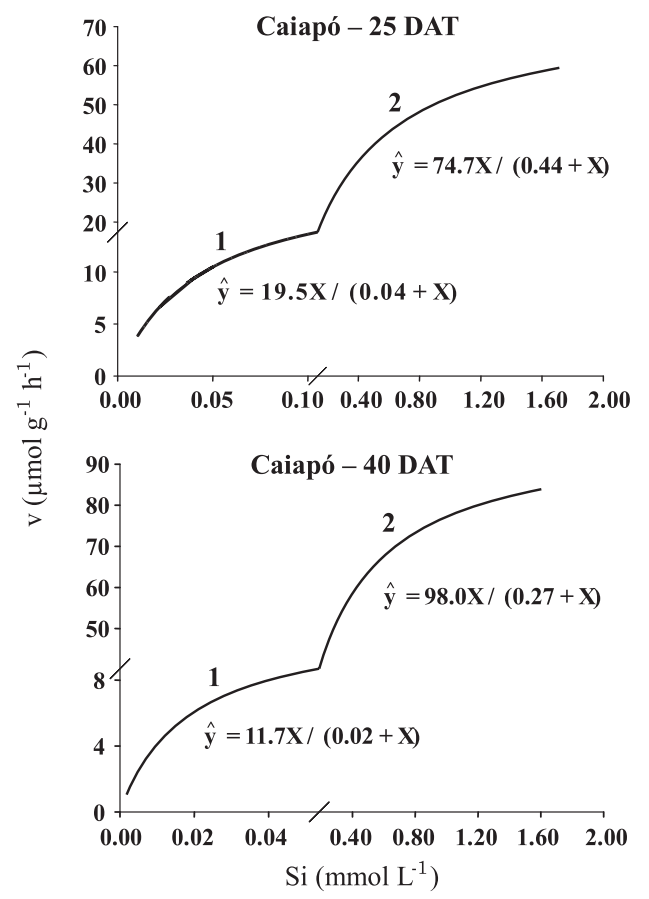

The observed $\mathrm{K}_{\mathrm{m}}$ values - ranging from 18.5 to $481.5 \mu \mathrm{mol} \mathrm{L}-1$ for $\mathrm{Si}$ - were much higher than for other minerals. For example, $\mathrm{P} \mathrm{K}_{\mathrm{m}}$ is between 1 and $5 \mu \mathrm{mol} \mathrm{L}{ }^{-1}$ (Kochian, 2000). This result indicates that the Si carrier in rice roots has low affinity for Si. A possible explanation for this low affinity is that, contrary to other minerals, Si is abundant in the soil solution and a high-affinity carrier is unnecessary (Tamai \& Ma, 2003). Another explanation would be the fact that $\mathrm{Si}$ is not an essential element for plants.

The $\mathrm{K}_{\mathrm{m}}$ value for the solution containing $0.1 \mathrm{mmol} \mathrm{L}^{-1} \mathrm{Si}$, regardless of the cultivar (Table 3), was 11 times smaller than the high-Si-dose solution, although the ratio between $\mathrm{Si}$ concentrations in the solutions was 17 . This demonstrates that carriers activated in the low concentration range have much more affinity with the nutrient than those in the high concentration range (Matias et al., 2003).

In general, parameters $\mathrm{V}_{\max }$ and $\mathrm{K}_{\mathrm{m}}$ decreased with plant age. Sacramento \& Rosolem (1997) also verified a reduction in the kinetic parameters $\mathrm{V}_{\max }$ and $\mathrm{C}_{\min }$ for $\mathrm{K}$ uptake by soybean plants, as a function of plant age.

For kinetic parameter $\mathrm{C}_{\min }$ - a threshold concentration below which the plant is unable to uptake the ion and, therefore, any increase in $\mathrm{C}_{\text {min }}$ values means a reduction in the nutrient uptake efficiency - it can be said that the results demonstrate that $\mathrm{C}_{\min }$ is also subject to modulation. Values for this variable were different between $\mathrm{Si}$
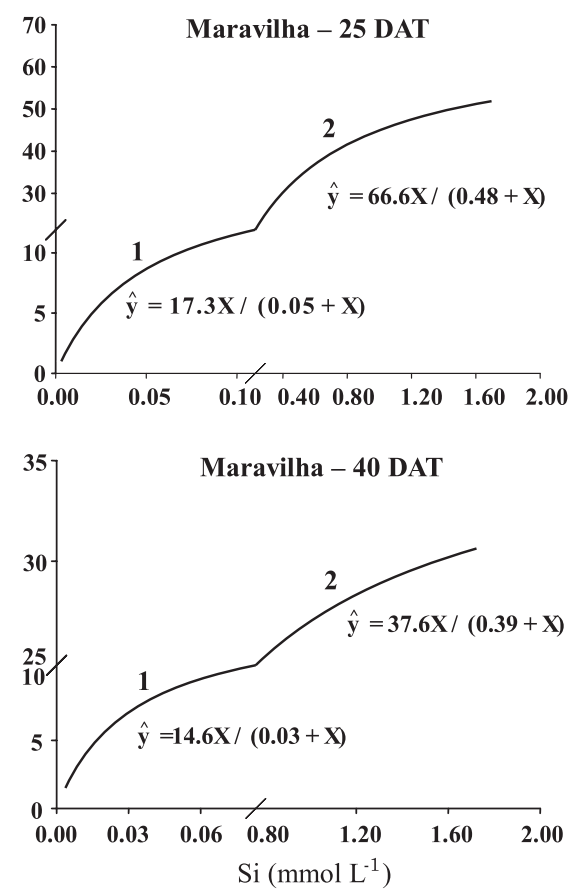

Figure 2. Silicon uptake velocity and participation of high - (1) and low-affinity uptake mechanisms (2) in rice cultivar roots 25 and 40 days after transplanting (DAT) as a function of Si concentration in the nutrient solution. 
doses for Caiapó after 25 days, and for Maravilha after 40 days (Table 3), with the highest values found for the lower Si dose. At the $0.1 \mathrm{mmol} \mathrm{L}^{-1}$ Si dose (Table 3), Caiapó had a higher $\mathrm{C}_{\min }$ value after 25 days and Maravilha had a higher $\mathrm{C}_{\min }$ value after 40 days.

It was noted that the application of the higher $\mathrm{Si}$ dose significantly increased $\mathrm{Si}$ contents in the aerial part and roots in both cultivars (Table 3), demonstrating the action of a low-affinity $\mathrm{Si}$ transport system. The low-affinity transport system is responsible for transporting nutrients found at high external concentrations, showing a linear increase in activity as a response to concentration, according to Wang et al., (1993) and Kronzucker et al., (1996) in a study on ammonium uptake kinetics. This system is responsible for maintaining great uptake in situations of high external availability of the nutrient (Borges et al., 2009).

Examples of increased Si contents in plant tissues due to Si fertilization are frequently reported in the literature, especially in the tropics, since in the case of Brazil, soils are Si-poor, due to their high degree of weathering (Barbosa Filho et al., 2001).

Among cultivars, only at the dose of $0.1 \mathrm{mmol} \mathrm{L}^{-1}$ Si after 25 days, no significant difference was observed for Si content in the aerial part. In the other treatments, the Si content was highest for the cultivar Maravilha, which belongs to the modern group (Table 3). Modern cultivars are more productive, smaller, have erect leaves (higher photosynthetic efficiency), and high tillering capacity (Breseghello et al., 1998). These traits allow a higher nutrient uptake.

It is worth noting that rice genotypes are quite different in their Si uptake capacity (Tamai \& Ma, 2003) and that these differences in the uptake process are associated with genetic traits that control inheritance for nutrient use efficiency. Environmental differences also play a role in the modulation of uptake kinetic parameters.

Silicon content in the root (Table 3) was not different in most treatments. Perhaps this is due to the fact that $\mathrm{Si}$ deposition occurs especially in the aerial part of the plant, as observed by several authors (Yoshida et al., 1962; Agarie et al., 1998). Only at the highest Si dose, after 25 days, the root Si content of Maravilha was higher than of Caiapó.

Silicon accumulation in the aerial part (Table 4) was higher at the dose of $1.7 \mathrm{mmol} \mathrm{L}^{-1}$ than at $0.1 \mathrm{mmol} \mathrm{L}^{-1}$, in both samplings. No differences were observed between cultivars. The same is valid for $\mathrm{Si}$ accumulation in the entire plant (Table 4). However, Faria Junior et al. (2009) and Mauad et al. (2011) observed differences between rice genotypes for $\mathrm{Si}$ accumulation.
Maybe the difference in $\mathrm{Si}$ accumulation between cultivars was limited by the maximum Si dose which, even though considered high, was low in relation to the Si uptake capacity of this plant. However, the use of higher doses than in this study from the source used here would be difficult, since values of $>2.0 \mathrm{mmol} \mathrm{L}^{-1} \mathrm{Si}$ in the nutrient solution would lead to Si precipitation.

The uptake efficiency of the plants grown at the lower Si dose was lower. It can be said that the uptake was probably not reduced because the uptake system was inefficient, but due to the low $\mathrm{Si}$ availability (Table 4).

In terms of uptake efficiency, after 25 days at the higher Si dose and after 40 days at the lower Si dose cultivar Maravilha showed higher UE. This may be due to the smaller root diameter and greater root system (Table 2) of this cultivar in the respective evaluations, which resulted in an advantageous $\mathrm{Si}$ uptake (Table 4). On the other hand, at the higher Si dose after 40 days, the UE of Caiapó had a higher UE. This was possibly related to kinetic and morphological root factors that are directly related to uptake mechanisms occurring at the soil-root interface, since this cultivar had the highest average $\mathrm{V}_{\max }$ (Table 3) and smallest root diameter values (Table 2), resulting in greater UE.

The result found for utilization efficiency (UTLE) was opposite to the result found for the UE. A difference between Si doses was also observed; however, the highest UTLE value was found at the dose of $0.1 \mathrm{mmol} \mathrm{L}^{-1} \mathrm{Si}$, demonstrating that $\mathrm{Si}$ is not associated with plant growth processes. Differences between cultivars only occurred at the lower Si dose after 40 days, with Caiapó providing the highest UTLE value (Table 4).

After 25 days, no difference was found for the root/aerial part ratio (RT/AEP). However, after 40 days the highest values were found for cultivar Maravilha, both at the higher and the lower Si doses (Table 4). An influence of Si doses was only observed for Caiapó, for which the RT/AEP ratio was higher at the lower Si dose.

A high root/aerial part ratio can be beneficial when soil fertility is low, because a greater root area is available to meet the plant needs. On the other hand, greater translocation of photoassimilates into the root system may limit the growth of the aerial part, decreasing the photosynthetically active area and reducing crop productivity when the stress condition persists for a long time. This physiological adjustment of the plant has a metabolic cost that can be irreversible, depending on the plant developmental stage.

The RT/AEP ratio was inversely proportional to the total plant dry matter yield. After 40 days, 
Table 4. Silicon accumulation in the aerial part (AEP), root (RT), and the entire plant (EP), Si uptake efficiency: (UE) = (total Si accumulation in the plant/root dry matter yield), utilization efficiency: (UTLE) $=(\text { total dry matter yield })^{2} /($ total $\mathrm{Si}$ accumulation in the plant), and root/aerial part ratio: (RT/AEP) $=$ (root dry matter yield/aerial part dry matter yield) of rice cultivars at different Si concentrations in the nutrient solution 25 and 40 days after transfer into the growth solution

\begin{tabular}{|c|c|c|c|c|c|c|}
\hline \multirow{4}{*}{ Cultivar } & \multicolumn{6}{|c|}{ Day of growth } \\
\hline & \multicolumn{3}{|c|}{25 days } & \multicolumn{3}{|c|}{40 days } \\
\hline & \multicolumn{6}{|c|}{ Si levels $\left(\mathrm{mmol} \mathrm{L}^{-1}\right)$} \\
\hline & 1.7 & & 0.1 & 1.7 & & 0.1 \\
\hline & \multicolumn{6}{|c|}{$\mathrm{AEP}$ (mg/plant) } \\
\hline Caiapó & $41.0 \mathrm{aA}$ & & $6.3 \mathrm{aB}$ & $108.6 \mathrm{aA}$ & & $5.5 \mathrm{aB}$ \\
\hline Maravilha & $38.4 \mathrm{aA}$ & & $4.8 \mathrm{aB}$ & $97.0 \mathrm{aA}$ & & $9.5 \mathrm{aB}$ \\
\hline \multirow[t]{2}{*}{$\mathrm{CV}(\%)$} & \multicolumn{3}{|c|}{13.3} & \multicolumn{3}{|c|}{23.4} \\
\hline & \multicolumn{6}{|c|}{$\mathrm{RT}$ (mg/plant) } \\
\hline Caiapó & $0.81 \mathrm{aA}$ & & $0.65 \mathrm{aA}$ & $2.05 \mathrm{bA}$ & & $1.91 \mathrm{bA}$ \\
\hline Maravilha & $0.73 \mathrm{aA}$ & & $0.60 \mathrm{aA}$ & $3.03 \mathrm{aA}$ & & $2.44 \mathrm{aB}$ \\
\hline \multirow[t]{2}{*}{ CV (\%) } & & 26.4 & & & 15.8 & \\
\hline & \multicolumn{6}{|c|}{$\mathrm{EP}(\mathrm{mg} / \mathrm{plant})$} \\
\hline Caiapó & $41.8 \mathrm{aA}$ & & $6.9 \mathrm{aB}$ & $110.7 \mathrm{aA}$ & & $7.4 \mathrm{aB}$ \\
\hline Maravilha & $39.1 \mathrm{aA}$ & & $5.4 \mathrm{aB}$ & $100.1 \mathrm{aA}$ & & $12.0 \mathrm{aB}$ \\
\hline \multirow[t]{2}{*}{ CV $(\%)$} & & 12.6 & & & 22.8 & \\
\hline & & & & & & \\
\hline Caiapó & $128.8 \mathrm{bA}$ & & $21.8 \mathrm{aB}$ & $148.3 \mathrm{aA}$ & & $6.2 \mathrm{bB}$ \\
\hline Maravilha & $177.3 \mathrm{aA}$ & & $19.5 \mathrm{aB}$ & $80.0 \mathrm{bA}$ & & $30.4 \mathrm{aB}$ \\
\hline \multirow[t]{2}{*}{ CV (\%) } & & 21.1 & & & 24.1 & \\
\hline & \multicolumn{6}{|c|}{ UTLE $\left(\mathrm{g}^{2} \mathrm{mg}^{-1}\right)$} \\
\hline Caiapó & $0.09 \mathrm{aB}$ & & $0.59 \mathrm{aA}$ & $0.81 \mathrm{aB}$ & & $16.77 \mathrm{aA}$ \\
\hline Maravilha & $0.07 \mathrm{aB}$ & & $0.47 \mathrm{aA}$ & $0.64 \mathrm{aB}$ & & $5.33 \mathrm{bA}$ \\
\hline \multirow[t]{2}{*}{ CV $(\%)$} & & 31.9 & & & 24.1 & \\
\hline & \multicolumn{6}{|c|}{ RT/AEP } \\
\hline Caiapó & $0.21 \mathrm{aA}$ & & $0.20 \mathrm{aA}$ & $0.10 \mathrm{bB}$ & & $0.14 \mathrm{bA}$ \\
\hline Maravilha & $0.20 \mathrm{aA}$ & & $0.23 \mathrm{aA}$ & $0.19 \mathrm{aA}$ & & $0.22 \mathrm{aA}$ \\
\hline CV (\%) & \multicolumn{3}{|c|}{26.4} & \multicolumn{3}{|c|}{18.1} \\
\hline
\end{tabular}

Means followed by the same lower case letter, in the column, and by the same upper case letter, in the row, did not differ from one another by the LSD test at $5 \%$. CV: coefficient of variation.

the cultivars showed higher TDMY (Table 2) and lower RT/AEP ratio (Table 4) than the 25-day assessment; this decrease in RT/AEP ratio values was probably due to a greater growth of the aerial part in detriment of the roots, i.e., at that tmie, most photoassimilates were being transported to the developing aerial part (growth and development of tillers and leaves).

\section{CONCLUSIONS}

1. The low-affinity $\mathrm{Si}$ uptake system is more developed in cultivar Caiapó than in Maravilha; $\mathrm{Si}$ uptake of Caiapó is more efficient at high availability of the mineral.

2. Higher Si concentrations in the nutrient solution do not increase rice dry matter yield.

3. In older plants, the maximum uptake rates $\left(\mathrm{V}_{\max }\right)$ and $\mathrm{K}_{\mathrm{m}}$ values are lower than in younger plants.
4. When developing under low Si availability, the cultivars Caiapó and Maravilha depend on higher $\mathrm{C}_{\min }$ values to be able to absorb this mineral.

\section{ACKNOWLEDGEMENTS}

The authors are indebted to the State of São Paulo Research Foundation (FAPESP) for financial support and a graduate scholarship of the first author, and to the National Council for Scientific and Technological Development (CNPq) for an award for excellence in research of the second author.

\section{LITERATURE CITED}

AGARIE, S.; HANAOKA, N.; UENO, O.; MIYAZAKI, A.; KUBOTA, F.; AGATA, W. \& KAUFMAN, P.B. Effects of silicon on tolerance to water deficit and heat stress in rice plants (Oryza sativa L.), monitored by electrolyte leakage. Plant Produc. Sci., 1:96-103, 1998. 
BARBER, S.A. Soil nutrient bioavailability: A mechanistic approach. New York, John Wiley, 1984. 398p.

BARBOSA FILHO, M.P.; SNYDER, G.H.; FAGERIA, N.K.; DATNOFF, L.E. \& SILVA, O.F. Silicato de cálcio como fonte de silício para o arroz de sequeiro. R. Bras. Ci. Solo, 25:325-330, 2001.

BORGES, E.A.; LOSS, A.; SILVA, E.E.; SOUZA, S.R. \& FERNANDES, M.S. Cinética de absorção de amônio e efluxo de prótons em variedades de milho. Semina Ci. Agr., 30:513-526, 2009.

BRESEGHELLO, F.; CASTRO, E.M. \& MORAIS, O.P. Cultivares de arroz. In: BRESEGHELLO, F. \& STONE, L.F., ed. Tecnologia para arroz de terras altas. Santo Antônio de Goiás, Embrapa Arroz e Feijão, 1998. 161p.

CLAASSEN, N. \& BARBER, S.A. A method for characterizing the relation between nutrient concentration and flux into roots of intact plants. Plant Physiol., 54:564-568, 1974.

CLARKSON, D.T. \& HAWKESFORD, M.T. Molecular biological approaches to plant nutrition. In: BARROW, N.J., ed. Plant nutrition - from genetic engineering to field practice. London, Kluwer Academic Press, 1993. p.23-33.

CORRÊA, J.C.; COSTA, A.M.; CRUSCIOL, C.A.C. \& MAUAD, M. Doses de boro e crescimento radicular e da parte aérea de cultivares de arroz de terras altas. R. Bras. Ci. Solo, 30:1077-1082, 2006

ELLIOTT, C.L. \& SNYDER, G.H. Autoclave-induced digestion for the colorimetric determination of silicon in rice straw. J. Agric. Food Chem., 39:1118-9, 1991.

ELZAM, O.E.; RAINS, D.W. \& EPSTEIN, E. Ion transport kinetics in plant tissue: Complexity of the chloride absorption isotherm. Biochem. Biophys. Res. Comm., 15: 273-276, 1964.

EPSTEIN, E. \& HAGEN, C.E. A kinectic study of the absorption of alkali cations by barley roots. Plant Physiol., 27:457-474, 1952.

EPSTEIN, E. \& BLOOM, A.J. Nutrição mineral de plantas: princípios e perspectivas. 2.ed. Londrina, Planta, 2006. 403p.

EPSTEIN, E.; RAINS, D.W. \& ELZAM, O.E. Resolution of dual mechanisms of potassium absorption by barley roots. Proc. Nat. Acad. Sci., 49:684-692, 1963.

FARIA JUNIOR, L.A.; CARVALHO, J.G.; PINHO, P.J.; BASTOS, A.R.R. \& FERREIRA, E.V. Produção de matéria seca, teor e acúmulo de silício em cultivares de arroz sob doses de silício. Ci. Agrotec., 33:1034-1040, 2009.

FURLANI, A.M.C. \& FURLANI, P.R. Composição e pH de soluções nutritivas para estudos fisiológicos e seleção de plantas em condições nutricionais adversas. Campinas, Instituto Agronômico de Campinas, 1988. 34p. (Boletim Técnico, 121)

KOCHIAN, L.E. Molecular physiology of mineral nutrient acquisition, transport and utilization. In: BUCHANAN, B.B.; GRUISSEM, W. \& JONES, R.L. eds. Biochemistry and molecular biology of plants. Maryland, American Society of Plant Physiologists, 2000. p.1204-1247.
KORNDÖRFER, G.H.; COELHO, N.M.; SNYDER, G.H. \& MYZUTANI, C.T. Avaliação de métodos de extração de silício em solos cultivados com arroz de sequeiro. R. Bras. Ci. Solo, 23:101-106, 1999.

KORNDORFER, P.H.; SILVA, G.C.; TEIXEIRA, I.R.; SILVA, A.G. \& FREITAS, R.G.S. Efeito da adubação silicatada sobre gramíneas forrageiras e características químicas do solo. Pesq. Agropec. Trop., 49:119-125, 2010.

KRONZUCKER, H.J.; SIDDIQI, M.Y. \& GLASS, A.D.M. Kinetics of $\mathrm{NH}_{4}{ }^{+}$influx in spruce. Plant Physiol., 110:773-779, 1996.

LIANG, Y.; SUN, W.; ZHU, Y.G. \& CHRISTIE, P. Mechanisms of silicon-mediated alleviation of abiotic stresses in higher plants: A review. Environ. Pollut., 147:422-428, 2007.

MA, J.F.; GOTO, S.; TAMAI, K. \& ICHII, M. Role of root hairs and lateral roots in silicon uptake by rice. Plant Physiol., 127:1773-1780, 2001.

MA, J.F. \& TAKAHASHI, E. Soil, fertilizer and plant silicon research in Japan. Amsterdam, Elsevier Science, 2002. 274p.

MALAVOLTA, E. Manual de nutrição mineral de plantas. São Paulo, Agronômica Ceres, 2006. 638p.

MATIAS, G.C.S.; COMETTI, N.N. \& FERNANDES, M.S. Cinética de absorção de nutrientes por alface em hidroponiaNFT - com duas concentrações da solução nutritiva. In: CONGRESSO BRASILEIRO DE CIÊNCIA DO SOLO, 29., 2003, Ribeirão Preto. Anais... Botucatu, Sociedade Brasileira de Ciência do Solo, 2003. CD ROM.

MAUAD, M.; CRUSCIOL, C.A.C. \& GRASSI FILHO, H. Produção de massa seca e nutrição de cultivares de arroz de terras altas sob condição de déficit hídrico e adubação silicatada. Semina: Ci. Agr.., 32:939-948, 2011.

MAUAD, M.; GRASSI FILHO, H.; CRUSCIOL, C.A.C. \& CORREAA, J.C. Teores de silício no solo e na planta de arroz de terras altas com diferentes doses de adubação silicatada e nitrogenada. R. Bras. Ci. Solo, 27:867-873, 2003.

MICHAELIS, L. \& MENTEN, M. Die Kinetik der Invertinwirkung. Biochem. J., 49:333-369, 1913.

PAVINATO, P.S.; AGUIAR, A.; CASTRO, G.S.A. \& CRUSCIOL, C.A.C. Boro em arroz de terras altas cultivado em solução nutritiva. Bragantia, 68:743-751, 2009.

RUIZ, H.A. \& FERNANDES FILHO, E.I. Cinética: Software para estimar as constantes Vmax e Km da equação de MichaelisMenten. In: REUNIÃO BRASILEIRA DE FERTILIDADE DO SOLO E NUTRIÇÃO DE PLANTAS, 20., 1992, Piracicaba. Anais... Piracicaba, Sociedade Brasileira de Ciência do Solo, 1992. p.124-125.

SACRAMENTO, L.V. \& ROSOLEM, C.A. Cinética de absorção de potássio e seus ajustes em plantas de soja em função da idade e estado nutricional. R. Bras. Ci. Solo, 21:213-219, 1997.

SAVANT, N.K.; SNYDER, G.H. \& DATNOFF, L.E. Silicon management and sustainable rice production. Adv. Agron., 58:151-199, 1997. 
SIDDIQI, M.Y. \& GLASS, A.D.M. Utilization index: A modified approach to the estimation and comparison of nutrient efficiency in plants. J. Plant Nutr., 4:289-302, 1981.

SWIADER, J.M.; CHYAN, Y. \& FREIJI, F.G. Genotypic differences in nitrate uptake and utilization efficiency in pumpkin hybrids. J. Plant Nutr., 17:1687-1699, 1994.

TAMAI, K. \& MA, J.E. Characterization of silicon uptake by rice roots. New Phytol., 158:431-436, 2003.

TENNANT, D. A test of a modified line intercept method of estimating root length. J. Ecol. Appl., 63:995-1001, 1975.

VERMAS, T.S. \& MINHAS, R.S. Effect of iron and manganese interaction on paddy yield and iron and manganese nutrition in silicon-treated and untreated soil. Soil Sci., 147:107-115, 1989.
WANG, M.Y.; SIDDIQI, M.Y.; RUTH, T.J. \& GLASS, A.D.M. Ammonium uptake by rice roots. II. Kinetics of $13 \mathrm{NH}_{4}{ }^{+}$ influx across the plasmalemma. Plant Physiol., 103:12591267, 1993.

WIRÉN, N.; GAZZARRINI, S.; GOJON, A. \& FROMMER, W.B. The molecular physiology of ammonium uptake and retrieval. Curr. Opin. Plant Biol., 3:254-261, 2000.

YOSHIDA, S.; OHNISHI, Y. \& KITAGISHI, K. Chemical forms mobility and deposition of silicon in rice plant. Soil Sci. Plant Nutr., 8:15-21, 1962. 
